\title{
Perspektif Praktisi Televisi Indonesia terhadap Konvergensi Televisi dan Internet dalam Persaingan Penyajian Informasi di Internet
}

\author{
Muhammad Adi Pribadi ${ }^{1}$, Muhammad Gafar Yoedtadi ${ }^{2}$ dan Kurniawan Hari Siswoko $^{3}$ \\ ${ }^{1}$ Email: adiposts@gmail.com \\ 2Email: yudtadi@gmail.com \\ ${ }^{3}$ Email: kurniawan.hari@gmail.com
}

\begin{abstract}
ABSTRAK
Masyarakat Indonesia mulai menggunakan internet untuk mencari informasi. Jumlah pengguna internet terus bertambah dari tahun ke tahun. Biaya internet dan teknologi komunikasi memudahkan masyarakat untuk mendapatkan informasi. Beberapa stasiun televisi di Indonesia melihat perubahan perilaku pemirsanya yang mulai mencari berita di Internet. Jumlah penyedia informasi melalui internet semakin banyak. Perubahan pola pencarian berita oleh pemirsa televisi dan persaingan dengan penyedia informasi di internet menyebabkan terjadinya konvergensi televisi dan internet pada tiga stasiun televisi di Indonesia. Ke tiga stasiun televisi tidak hanya menyediakan informasi melalui saluran televisi saja tetapi mereka juga menyediakan informasi melalui internet. Informasi yang cepat dan akurasi yang bisa dipertanggung jawabkan oleh stasiun televisi memberi keuntungan tersendiri bagi masyarakat. Perubahan ini memberikan keuntungan bagi stasiun televisi karena perubahan ini menjadi penambah pendapatan bagi stasiun televisi. Penelitian ini menggunakan metodologi kualitatif dengan metode fenomenologi. Dengan teknik ini, peneliti mengumpulkan dan menganalisis data yang diperoleh dari tiga jurnalis pada tiga stasiun televisi nasional yang masuk dalam kategori 10 besar menurut AC NIELSEN.
\end{abstract}

Kata kunci: televisi, konvergensi, internet

\section{PENDAHULUAN}

Di era teknologi dan komunikasi saat ini, stasiun televisi berupaya untuk menyediakan informasi dalam waktu cepat dan terkini untuk kepentingan pemirsanya karena pemirsa menginginkan informasi dalam bentuk berita dan hiburan yang mudah didapat dan terkini sehingga mereka tidak tertinggal informasi. Namun, Stasiun televisi harus berhadapan dengan penyedia informasi hiburan dan berita yang menggunakan media internet dimana para pelakunya mampu memberikan kecepatan informasi terkini, cepat penyajiannya dan bisa di akses dimana saja hanya dengan menggunakan telpon genggam.

Semakin murahnya harga telpon genggam yang telah bertambah fungsinya menjadi mesin pencari informasi, akibat kemajuan teknologi, memudahkan para penggunanya untuk mendapatkan informasi. Kemajuan teknologi mampu merubah pola prilaku masyarakat dalam mencari informasi karena mereka memilih teknologi yang mampu meberikan informasi dalam waktu yang singkat, bisa dijangkau hampir di semua tempat dengan harga yang murah. Telpon genggam dan internet menjawab kebutuhan masyarakat Indonesia saat ini dan peralihan media telah terjadi.

Hal ini tentu akan mengusik para pemilik stasiun televisi karena para pencari informasi ini bisa beralih dalam pencarian informasinya dari stasiun televisi ke internet. Peralihan ini bisa mengganggu pendapatan stasiun televisi dari iklan. Para pengiklan bisa memilih perusahaan perusahaan yang memiliki situs berita dan informasi yang dianggap mampu menarik perhatian pembacanya sehingga para pengiklan bisa menaruh iklannya disana. Kekhawatiran pemilik stasiun televisi memang wajar karena mereka melihat kondisi pemilik koran yang pertumbuhan pendapatannya mengalami penurunan yang berarti di periode 2013-2014 dibandingkan dengan periode-periode sebelumnya, Menurut Nielsen Advertising Information Service (Persatuan Perusahaan Periklanan, 2015). 
Disisi yang lain, para pengiklan bisa melihat perkembangan jumlah orang yang telah melihat iklannya di Internet dalam waktu singkat sehingga pengiklan bisa memantau perkembangannya. Sedangkan beriklan di televisi menjadi tantangan tersendiri bagi pengiklan karena mereka tidak bisa melihat perkembangannya secara langsung untuk melihat perkembangan iklannya kecuali mereka mau membayar lebih kepada pihak pemantau informasi seperti AC NIELSEN untuk melihat tingkat paparan iklannya di televisi kepada masyarakat.

Berkaitan dengan keefektifan iklan di internet, Penelitian yang dilakukan oleh Percy, Rossiter dan Elliot (2004) awalnya menunjukkan bahwa internet tidak mampu memberikan keefektifan dalam komunikasi pemasaran. Hasil penelitiann mereka mengalami perubahan seperti yang tertulis dalam bukunya, Strategic Advertising Management, bahwa internet mampu mempengaruhi target konsumen (Percy dan Elliot, 2012). Melihat kondisi ini, pengiklan tentu akan menggunakan internet untuk kegiatan komunikasi pemasaran sehingga stasiun televisi perlu menggunakan internet untuk mendapatkan peluang ini dari pengiklan.

Sosial media menjadi tantangan tersendiri juga bagi televisi karena setiap orang bisa menyampaikan informasi di internet. Mereka dikenal sebagai jurnalisme warga. Masyarakat bisa memasukkan berita-berita yang mereka anggap penting kemudian informasi tersebut bisa dibaca oleh banyak pihak. Walaupun begitu, informasi yang disampaikan oleh masyarakat di Internet masih perlu di pertimbangkan tingkat kebenaran informasinya serta pertanggung jawabannya. Stasiun televisi masih bisa dipercaya oleh masyarakat dari segi penyampaian informasi karena para jurnalis televisi melakukan verifikasi data untuk melihat kebenaran informasi sehingga mereka bisa mempertanggung jawabkan pada publik.

Penelitian ini berupaya untuk mengungkap bagaimana pandangan para praktisi televisi Indonesia terhadap konvergensi televisi dan internet dalam mengatasi persaingan dengan perusahaan yang menggunakan internet untuk menyebarkan informasi. Pandangan para praktisi di stasiun televisi akan memberikan gambaran kondisi pertelevisian di Indonesia dalam mengatasi persaingan dengan perusahaan yang menggunakan media internet, peluang yang didapat stasiun televisi dari internet, perkembangan organisasi, dan penjelasan tentang seiringnya kecepatan penyampaian informasi dengan akurasi informasi.

\section{Tinjauan Pustaka}

Indonesia memiliki jumlah penduduk sebesar 253.609.643 di tahun 2014. Namun penyebaran penduduknya tidak merata. Menurut data Persatuan Perusahaan Periklanan Indonesia, dari 34 provinsi yang ada di Indonesia, penduduknya terkonsentrasi di beberapa daerah seperti Jakarta terdapat 9. 769.000 jiwa, Surabaya memiliki populasi 2.787.000 jiwa, Bandung terdapat 2.429.000 jiwa, Medan terdapat 2.118.000 jiwa, Semarang terdapat 1.573.000 jiwa dan Palembang terdapat 1.455.000 jiwa (Persatuan Perusahaan Periklanan Indonesia, 2015).

Dilihat dari jumlah penduduk, Indonesia memang menjadi tempat yang menarik untuk investor asing untuk masuk ke Indonesia sejak era Orde baru. Sejak peralihan pemerintahan dari Orde lama ke orde baru, banyak investor asing masuk ke Indonesia untuk melakukan investasi dan perdagangan. Mereka membutuhkan sarana komunikasi pemasaran untuk memperkenalkan merek dan produknya. Televisi, radio dan koran adalah sarana untuk melakukan kegiatan periklanan di era 1970an. Bahkan 60 persen kegiatan komunikasi pemasaran dilakukan di televisi pada saat itu. 
TVRI (Televisi Republik Indonesia) adalah televisi pertama di Indonesia sehingga TVRI menjadi media satu-satunya untuk kegiatan periklanan di televisi saat itu. Pada tahun 1980, kegiatan periklanan di televisi dilarang oleh pemerintah di era orde baru karena iklan di TVRI dianggap menciptakan konsumerisme bagi masyarakat. Saat itu, kegiatan periklanan beralih ke koran dan radio. Koran Kompas menjadi media tempat iklan favorit bagi banyak merek dan produk saat itu (PT FORTUNE INDONESIA TBK, 2014).

Menurut Persatuan Perusahaan Periklanan Indonesia, sejak berdirinya di tahun 1962, TVRI menjadi stasiun televisi satu-satunya yang dimiliki oleh Indonesia hingga tahun 1987. TVRI adalah stasiun televisi nasional yang dimiliki oleh pemerintah dari awal berdirinya hingga saat ini. Sejak tahun 1988, mulailah bermunculan stasiun televisi swasta. Rajawali Citra Televisi Indonesia (RCTI) menjadi awal berdirinya stasiun televisi swasta. Kemudian muncul Surya Citra Televisi (SCTV), Televisi Pendidikan Indonesia (TPI), ANTV, INDOSIAR, METRO TV, TRANS TV dll (Persatuan Perusahaan Periklanan Indonesia. 2005).

Stasiun televisi di Indonesia menyajikan program - program televisi seperti berita dan hiburan. Namun beberapa stasiun televisi ada yang memprioritaskan berita daripada hiburan ataupun sebaliknya.

Selain televisi, Internet menjadi media pilihan bagi warga Indonesia. Jumlah pengguna internet di Indonesia terus meningkat dari tahun ke tahun menurut Roy Morgan. Jumah pengguna Internet di Indonesia menurut Roy Morgan mencapai 19.766.000 orang. Waktu yang dapat dihabiskan per hari untuk berselancar di Internet adalah 13 jam untuk pria dan 12 jam untuk wanita (Persatuan Perusahaan Periklanan Indonesia. 2015). Perkembangan jumlah pengguna internet dari tahun ke tahun menjadi hal yang wajar karena biaya internet dan medianya murah.

Melihat perkembangan pengguna internet, stasiun televisi mulai menggunakan internet untuk mendukung kegiatan pemberitaannya. Menjadi suatu hal yang wajar bagi stasiun televisi mengikuti perkembangan teknologi untuk melayani kebutuhan informasi pemirsa dan mengatasi persaingan (Noor, 2010).

Dalam persaingan, Michael E Porter (1994) berpendapat bahwa perusahaan yang mengikuti perkembangan teknologi dan mampu menurunkan biaya produksinya menjadi perusahaan yang mampu bersaing dengan para pesaingnya. Bahkan, Struktur organisasi perusahaan bisa mengalami perubahan untuk mengikuti perkembangan yang ada di masyarakat (Hill, Jones, Galvin. 2004).

Namun begitu, penggunaan teknologi baru memerlukan pendanaan yang tidak sedikit sehingga kegiatan bisnis bisa berjalan lamban pada awalnya namun dengan berjalannya, waktu kesuksesan bisa di raih. Hal ini terjadi pada para pendiri YOUTUBE dan FACEBOOK yang memulai kegiatan usahanya dalam keadaan kesusahan karena mereka harus mencari dana segar untuk menutupi biaya operasionalnya yang membengkak tetapi saat ini mereka menikmati keuntungan besar dari usahanya di bidang media sosial (Fish, 2012).

Jika Stasiun televisi tidak menggunakan media internet untuk mendukung kegiatan usahanya tentu hal ini tidak menguntungkan bagi stasiun televisi karena bisa saja stasiun televisi tersebut ditinggalkan oleh para pemirsanya karena masyarakat tidak hanya menggunakan sarana televisi untuk mendapatkan informasi tetapi juga melalui internet. Penggunaan internet saat ini adalah kesempatan bagi perusahaan untuk mendekatkan merek dan produknya. Menurut Kotler dan 
Keller (2012), perusahaan-perusahaan menggunakan internet untuk bisa berkomunikasi dengan target khalayaknya melalui website dan media sosial.

Penggunaan internet dalam aktivitas stasiun televisi akan memudahkan dan mendukung kecepatan mendapatakan informasi bagi target khalayaknya. Walaupun kecepatan untuk mendapatkan informasi bagi target khalayak menjadi hal yang penting, televisi harus tetap menjaga amanah masyarakat untuk mengawasi jalannya pemerintahan dan memberikan informasi yang benar. Untuk menjaga amanah ini, stasiun televisi perlu mengetahui sembilan elemen jurnalisme dari Bill Kovach dan Tim Rosentiel (2006). Yang pertama adalah kewajiban pertama jurnalisme adalah kebenaran. Walter Lipman berpendapat bahwa berita memiliki fungsi menandai pristiwa hingga menyadarkan masyarakat atas hal itu, oleh karenanya penting bagi sebuah berita untuk menjaga kebenaran agar berita didukung oleh fakta yang bisa menggambarkan kondisi nyata. Yang kedua adalah loyalitas pertama jurnalisme kepada warga. Aktivitas jurnalistik adalah untuk menjaga kepentingan masyarakat bukan untuk kepentingan segelintir kelompok, Individu serta kepentingan politik.

Yang ketiga adalah intisari jurnalisme adalah disiplin verifikasi. Verifikasi akan menguji kebenaran informasi sehingga terhindar dari ketidakjelasan informasi. Yang keempat adalah wartawan harus tetap Independen dari pihak yang mereka liput. Dengan sikap independen, jurnalis akan terhindari dari kepentingan status ekonomi, agama, ras, gender, dan etnis.

Yang kelima adalah jurnalis sebagai pemantau kekuasaan. Jurnalis harus menjaga fungsinya sebagai pengawas sosial. yang keenam adalah jurnalisme harus menghadirkan sebuah forum untuk mengkritik dan berdiskusi dengan publik. Pers harus menyediakan tempat dimana masyarakat dapat menyampaikan keluhan dan kritik serta komentar kepada pihak manapun dan dimanapun.

Yang ketujuh adalah jurnalis harus membuat hal penting menjadi menarik dan relevan. Jurnalis memiliki kemampuan untuk menampilkan informasi yang bisa membuat masyarakat ikut mengikuti perkembangan beritanya. Yang kedelapan adalah wartawan harus menjaga berita proporsional dan komprehensif. Jurnalis mampu memberikan informasi yang berkualitas bukan yang bersifat provokatif dan sensasional. Yang kesembilan, wartawan harus mendengarkan suara hatinya. Wartawan tetap tersadar untuk menjaga nilai-nilai yang benar.

\section{Tujuan dan Manfaat Penelitian}

Penelitian ini memiliki tujuan dan manfaat bagi para mahasiswa/wi, peneliti dan Dosen. Perkembangan teknologi telah mengembangkan format kerja dan organisasi stasiun televisi di Indonesia. Format kerja para jurnalis menjadi lebih banyak mereka tidak hanya dituntut untuk mencari berita dan menulisnya tetapi mereka perlu memiliki kemampuan untuk menyampaikan kepada masyarakat secara cepat, di mana saja, dan kapan saja selama teknologi masih mendukung pekerjaan mereka di lokasi tetapi mereka tetap harus menjaga etika jurnalistik. salah satu kelebihan jurnalis dalam menyampaikan berita di masyarakat di banding bukan jurnalis adalah nilai suatu berita terjamin kebenarannya karena panyampaian berita oleh jurnalis dikerjakan sesuai dengan etika jurnalistik yang mengedepankan kebenaran data melalui verifikasi.

Organisasi stasiun televisi mengalami perkembangan karena kemajuan teknologi yang ada menghasilkan unit bisnis-unit bisnis baru. Bisnis-bisnis baru terkait stasiun televisi memberikan 
keuntungan bagi stasiun televisi. Agar unit bisnis bisa berkembang diperlukan investasi uang, sumber daya manusia dan teknologi agar bisnis-bisnis baru bisa berjalan dengan baik.

Dengan mengetahui hasil penelitian ini, para mahasisiwa/wi dan peneliti bidang ilmu komunikasi mengetahui perkembangan ilmu pengetahuan di bidang jurnalistik atau televisi di Indonesia sehingga mereka bisa mengembangkan ilmu dan keterampilannya berdasarkan kebutuhan yang ada pada industri televisi.

Harapan lain dari hasil penelitian ini adalah para mahasiswa/wi, dosen dan peneliti mendapatkan ilmu pengetahuan mengenai perkembangan industri televisi di Indonesia. Jika buku - buku yang digunakan untuk perkuliahan banyak menjelaskan industri televisi di luar negeri, maka penelitian ini digunakan sebagai bahan mengajar untuk menjelaskan industri televisi di Indonesia sehingga mereka mendapatkan informasi yang berimbang.

\section{METODOLOGI PENELITIAN}

Penelitian ini menggunakan metodologi kualitatif dengan metode fenomenologi. Menurut Creswell (2013), fenomenologi digunakan peneliti untuk mencari pengalaman-pengalaman pelaku dalam menghadapi lingkungannya. Hussrel dan Merleau-Ponty menjelaskan bahwa fenomenologi digunakan peneliti untuk mengungkap tipe-tipe pengalaman, dalam bentuk deskripsi, dimasa lalu (Kuswarno, 2009).

Tantangan utama fenomenologi adalah menentukan titik awal dari kesadaran manusia yang bersifat bias. Kesadaran manusia dalam pandangan fenomenologi adalah sudut pandang pengalaman orang pertama. Proses penelitian dengan menggunakan metodologi ini mengedepankan pengalaman sadar, setengah sadar hingga pengalaman tidak sadar beserta latar belakang dari individu yang memiliki pengalaman atas situasi yang dihadapinya (Kuswarno, 2009).

Penelitian ini ingin mengungkap pengalaman para jurnalis televisi dalam menghadapi perkembangan dunia televisi dan persaingannya di era internet. Melihat dan mempelajari pengalaman hidup mereka sebagai jurnalis televisi menjadi dasar belajar bagi para mahasiswa/wi, peneliti, dan dosen untuk melihat perkembangan dunia pertelevisian di Indonesia saat ini.

Penelitian ini melibatkan tiga jurnalis dari tiga stasiun televisi swasta yang masuk dalam kategori 10 besar televisi swasta menurut AC Nielsen. Peneliti melakukan tanya jawab secara terpisah kepada tiga jurnalis di lokasi yang berbeda. Nama ketiga jurnalis, stasiun televisi, program televisi dan kelompok bisnisnya dirahasiakan untuk menjaga kepentingan dari ketiga jurnalis tersebut. Nama mereka akan diganti dengan inisial A, B, dan C. Sedangkan stasiun televisi tempat mereka bekerja menggunakan inisial stasiun 1, stasiun 2 dan stasiun 3 .

Proses wawancara direkam agar memudahkan dalam pengumpulan data. Setelah data terkumpul, peneliti membuat transkrip hasil wawancara dan melakukan analisa awal. Kemudian peneliti melakukan pertemuan kedua dengan ketiga jurnalis tersebut, pada waktu dan tempat berbeda untuk melakukan klarifikasi atas data yang terkumpul. Setelah data disetujui oleh narasumber, proses analisa informasi disesuaikan dengan hasil pertemuan terakhir dengan para narasumber. Proses analisa ini dibantu juga dengan penggunaan data-data yang didapat oleh para peneliti yang telah menghasilkan teori dan konsep yang ada berkaitan dengan komunikasi massa, etika, dan persaingan. 


\section{HASIL DAN PEMBAHASAN}

Stasiun televisi ditempat mereka bekerja telah menggunakan media internet untuk melayani kebutuhan informasi target khalayak dari segi kecepatan penyajian informasi dan mengatasi persaingan dengan penyedia berita dan hiburan melalui internet. Berikut adalah kutipan dari narasumber $\mathrm{A}, \mathrm{B}$, dan $\mathrm{C}$.

a. Narasumber A mengatakan,” perusahaan, baru ini betul-betul serius untuk menggarap online ini dilihat dari situ salah satunya perusahaan kami tidak hanya (menggunakan) website sekarang sudah punya sosial media seperti youtube".

b. Narasumber B mengatakan," kalo bagi industri tv, stasiun 2 gitu lah ya artinya masih jauh sebagai ancaman. Kalo untuk produksi tv nya iya (sebagai ancaman), kalo untuk industrinya saya nggak lihat sebagai ancaman karenakan yang terancam produksi tv-nya karena orangkan lagi nggak nonton tv yang berapa inch tapi orang nontonnya dari gadget" ...Nah bicara soal youtube, kita stasiun dua atau newsnya stasiun dua itu memploporinya sejak april tahun 2014 di youtube."

c. Narasumber C mengatakan," Keliat bahwa industri itu yang tumbuh dengan bandwith yang bertambah juga di Indonesia kemudian ada yang sangat kuat sekali itu yang mengacu pada perkembangan jaman yang memang sudah berubah, pendapat saya. Jadi kalo misalkan...eee... apakah berpengaruh ? signifikan pengaruhnya. Jadi sekarang itu para pengusaha, pegiat televisi khususnya, yang broadcast itu sudah mulai beralih dia udah mulai masuk ke New media, digital media dan lain sebagainya gitu, dan peralihan itu adalah untuk mengantisipasi bisnis karena perkembangan jaman kan menyebabkan begitu dan saya yakin iklanpun akan lari ke situ"

Pada intinya ketiga narasumber setuju bahwa prilaku masyarakat mencari informasi dari internet menguntungkan bagi perusahaan penyedia berita secara online dan mereka menyadari peralihan pencarian informasi dari televisi ke internet telah terjadi di masyarakat sehingga mereka perlu mengikuti perkembangan yang ada, dimana media internet seperti website dan sosial media di gunakan dalam penyebaran informasi oleh stasiun televisi untuk menyediakan informasi bagi khalayak dan mengatasi persaingan dengan penyedia informasi lain yang menggunakan media online. Hal ini tentu Sejalan dengan temuan Porter (1994) dan Noor (2010), perusahaan perlu mengikuti perkembangan teknologi yang ada untuk menghadapi persaingan dalam kecepatan penyebaran informasi dan perubahan prilaku masyarakat dalam mencari informasi.

Para jurnalis melihat ada peluang mendapat keuntungan dalam penggunaan internet dalam penyebaran informasi dengan menggunakan internet. Berikut adalah kutipannya.

a. Narasumber A mengatakan," Kalo dalam grup ini, perolehan iklan masih Stasiun 1 yang terbesar masih kuat. Berapa pendapatannya gh.com dengan dotcom dotcom lainnya ya rugi masih rugi. Sekarang ini tadi Saya bilang, ini eranya untuk membuang uang/menginvestasikan (teknologi)... suatu saat kita petik untungnya, sekarang dalam lima tahun masih investasi dalam lima tahun tapi dalam lima tahun kedepan era tv sudah mulai eee akan berubah karena kalo dilihat datanya silahkan googling coba cek dari tahun ketahun, kue iklan di online paling hanya 0 sekian persen lah. (Namun) dalam setahun terakhir mungkin dulu nol koma-nol koma sekarang mungkin satu atau dua persen bahkan mungkin 5 persen".

b. Narasumber B mengatakan," tahun 2014 news Stasiun 2 bikin channel di youtube, akhirnya kita advertise, bisa jadi uangkan mulai tahun 2014 bulan oktober. Itu kita merangkak kecil cuma $\$ 100$, \$200, sampai akhirnya di akhir tahun 2014 pendapatan kita bisa mencapai $\$ 10.000$ melihat ini menjadi peluang penghasilan ya penghasilan tambahan ya cost nya nol. 
c. Narasumber C mengatakan," dari sisi uang pemilik mengantisipasi itu dan saya lihat hampir semua grup yang ada di Indonesia, stasiun 3, dan lain sebagainya akan lari kesana jadi kita akan masuk ke era konvergen. Konvergen ini yang menggabungkan antara apa namanya media mainstream dengan new media. Itu harus bergandengan gitukan sekarang sudah masuk video on demand, studio yang tanpa buffering internet-internet yang menyertakan konten-konten TV semua sudah seperti itu. Jadi semua itu sudah border less secara bisnis juga peningkatan internet luar biasa sekali. Kuah iklan, orang - orang melirik ke internet dan itu faktanya memang sudah terjadi ditahun 90 an".

Perspektif para jurnalis menunjukkan bahwa peluang untuk menambah pendapatan melalui internet bisa diperoleh dari iklan apabila menggunakan media internet yang sudah ada seperti youtube. Sedangkan stasiun televisi yang masih belum mendapatkan keuntungan adalah stasiun televisi yang merintis sendiri media internetnya sehingga keuntungan baru didapat beberapa tahun kemudian. Namun secara umum, mereka sepakat terdapat peluang pendapatan dari Internet. Sejalan dengan pendapat Porter (1994), penggunaan teknologi baru akan mampu menekan biaya operasional, yang pada akhirnya memberikan keuntungan bagi perusahaan. Walaupun dalam beberapa perusahaan, seperti GOOGLE dan YOUTUBE, penggunaan teknologi menjadi mahal di awal penggunaanya tapi sering dengan berjalannya waktu perusahaan tersebut bisa mendapatkan keuntungan (Fish, 2012).

Ketiga stasiun televisi mengkombinasikan antara televisi dan internet dalam penyiarannya. Tampak bahwa kombinasi ini memperluas struktur organisasi. Berikut adalah pernyataan dari para jurnalis.

a. Jurnalis A mengatakan, "semua faktor fisik baik di news maupun diproduksi ama news menerima kenyataan terkait keniscayaan kita soal berubah dan itu untuk meyakinkan itu lumayan lama sampai akhirnya sudah kita pisah saja perusahaan ini yang online kita pisah ayo siapa yang ikut disini itu akhirnya dipaksakan seperti itu dan memang dipaksakan seperti itu"

b. Jurnalis B mengatakan," Ada, jadi per satu januari kemaren kita ada struktur website. Saya membidangi lahirnya website itu cuma distruktur saya hanya di board saja, nggak yang menangani langsung sehari-hari hanya board aja. Karena melibatkan semua bagian kan, ada sales, ada IT , ada corcomm, ada programming semua tanggung jawabnya. Karena saya di NEWS jadi tanggung jawab saya ke konten yang berhubungan dengan NEWS sama terkait upload youtube, upload video nah kita yang nangani news nya stasiun 2 ”.

c. Jurnalis C mengatakan," Ada (perkembangan struktur organisasi di) new media, yang saya tahu... masih anak perusahaannya".

Para wartawan sepakat telah terjadi perkembangan pada struktur organisasi untuk menciptakan kombinasi antara televisi dengan internet. Sejalan dengan pendapat Hill, Jones, dan Galvin (2004), Struktur organisasi di perusahaan mengalami perubahan mengikuti perkembangan bisnis dan sosial di masyarakat.

Berkaitan dengan kecepatan penyampaian informasi dengan akurasi informasi, para jurnalis televisi sepakat bahwa kebenaran informasi harus didahulukan dengan cara verifikasi data karena stasiun televisi harus menjaga kepercayaan masyarakat memiliki pendapat sebagai berikut.

a. Jurnalis B mengatakan," Kalo media online, kalo kita batasi media online gitu ya, itu eee mereka sebagai sumber informasi saja jadi info kita dapat dari media online kita cek kebenarannya, iya kan. Kalo kita cek media online dalam hal ini situs-situs berita, kita ambil 
kita cek ke tim dapat nggak lo ini karena walau bagaimanapun platform-nya beda nih, satu online, satu lagi tv."

b. Jurnalis C mengatakan," Tapi sebetulnya televisi yang ada di Indonesia memberitakan rumor, memeberitakan hal yang banyak salahnya pasti akan mengalami krisis kepercayaan media televisi itu sebaliknya orang semakin percaya media sosial, itu yang bahaya. Artinya publik kita akan disuguhi kebohongan, fitnah, ketidakadilan,dsb. Dia akan lebih percaya pada rumor yand di twitter dsb, kan belum teruji. Artinya sekarang ini, temen-temen profesional televisi dia harus memiliki image yang kuat, dia harus menumbuhkan informasi yang bisa dipercaya (oleh publik). Kalo tidak bisa menunjukkan informasi yang tidak bisa dipercaya akan kalah dengan media sosial. karena kecepatan (dimiliki) media sosial. saya ambil contoh seperti bom sarinah, media mana yang menayangkan media sosial, bukan televisi, radio. Orang tahunya dari twitter, FB, WHATSAPP, dsb. Ada bom dimana, dimana, padahal itu nggak terjadikan. kan televisi itu tanpa mengkoordinasikan apapun dibeberapa televisi langsung aja menayangkan "bom meledak di Palmerah" padahal itu tidak pernah terjadi. artinya dia itu dipertanyakan professionalism, pembawa-pembawa di newsroom nggak bisa seperti itu. Karenakan, informasi yang bisa dipertanggung jawabkan itu penyelewengan etika berat... Verfifikasi tidak boleh berubah, verifikasi itu rumusnya tidak boleh berubah rumusnya. Dia itu rumusnya harus sama standarnya tidak boleh berubah. Kan ada yang namanya, Kalo menurut bill kovak itu kan ada jurnalisme pengukuhan, ada jurnalisme verifikasi, ada standar jurnalisme yang paling tinggi yaitu jurnalisme pengakuan. Itu hanya pengakuan saja, kita tidak memandang kecepatan tetapi yang paling benar itu jurnalisme yang standar itu yang terverifikasi itu yang tidak boleh dilanggar. Dan itu (tv menceritakan tentang bom di Jakarta yang salah), eee, tidak ada verifikasi, oh verifikasinya harus verifikasi dia harus bener ketika apakah ada bom di palmerah dia harus tahu kalo itu bener terjadi dengan mengandalkan informasi dari kepolisian itu belum cukup seorang jurnalis harus datang ke TKP membenarkan bahwa benar terjadi disitu. karena membuktikan kan ketika polisi bilang iya ada bom disana (ternyata) tidak ada. artinya itu informasi dari tangan-tangan yang kita percayapun belum tentu benar jadi jangan sampai terjebak, verfifikasi number one, tidak boleh dilanggar dan tidak ada tawar menawar.

Para jurnalis sepakat bahwa kebenaran atas data-data yang diperoleh harus diutamakan daripada kecepatan karena hal ini menjadi nilai lebih dari suatu karya jurnalistik yang bisa di percaya oleh masyarakat. Untuk memperoleh kebenaran atas data, para jurnalis perlu melakukan verifikasi atas informasi yang diperolehnya pada sumber data tersebut. Hal ini sejalan dengan pendapat Kovach yang mengatakan bahwa karya jurnalistik harus mengedepankan kebenaran atas data melalui verifikasi sehingga pers bisa mendapatkan kepercayaan dari masyarakat (Kovach, 2006).

\section{KESIMPULAN DAN SARAN}

\section{Kesimpulan}

Hasil penelitian menunjukkan bahwa para jurnalis berpendapat bahwa konvergensi televisi dan internet memang perlu dilakukan oleh stasiun televisi untuk mengatasi persaingan dengan perusahaan yang penyedia informasi melalui internet kepada khalayak. Terdapat beberapa alasan yang mereka sampaikan terkait dengan konvergensi media yaitu adanya perubahan perilaku masyarakat dalam penggunaan media untuk mencari informasi, peluang pendapatan baru, organisasi berkembang mengikuti perubahan teknologi dan masyarakat, etika jurnalis dikedepankan untuk mendapat kepercayaan masyarkat.

Perilaku masyarakat dalam mencari informasi mulai bergeser dari televisi ke media internet karena perkembangan teknologi komunikasi memudahkan masyarakat untuk mendapatkan 
informasi dimana saja dan kapanpun. Sedangkan informasi melalui televisi hanya diperoleh masyarakat pada saat mereka di rumah sehingga ruang gerak masyarakat untuk mendapat informasi terbatas oleh ruang dan waktu.

Penggunaan media internet memberikan tambahan pendapatan bagi stasiun televisi. Ruang iklan di telivisi dibatasi oleh pemerintah sehingga banyak pengiklan yang tidak bisa mengiklankan produknya di televisi. Dengan konvergensi televisi dengan media internet, para pengiklan memiliki kesempatan untuk mengiklankan produk barang dan jasanya melalui media internet yang dimiliki oleh stasiun televisi.

Konvergensi televisi dan internet mengembangkan struktur organisasi stasiun televisi. Penggunaan media internet pada stasiun televisi perlu mengedepankan kualitas pelayanan pada khalayak dari segi akurasi data dan kecepatan. Untuk menjaga kualitas informasi dan kecepatan penyampaiannya pada masyarakat diperlukan tim khusus untuk menangani media internet yang menjadi ladang bisnis baru.Hal ini menyebabkan berkembangnya struktur organisasi.

Penggunaan media internet di stasiun televisi adalah untuk memberikan informasi pada khalayak dalam mendapatkan informasi yang cepat, namun etika jurnalistik menjadi yang utama dalam menghasilkan karya jurnalistik. Jurnalis yang menjalankan etika jurnalistik menjadi modal kepercayaan masyarakat pada pers.

\section{Saran}

Setiap penelitian memiliki kelemahan. Banyak faktor menyebabkan timbulnya kelemahan, baik dari segi metode dan metodologi. Peneliti berharap adanya penelitian lanjutan berkait dengan kovergensi media yang terjadi di stasiun televisi dengan menggunakan metode kuantitatif untuk mendapatkan standarpengukuran keberhasilan televisi dalam menggunakan media internet.

Apabila terdapat penelitian yang menggunakan metode dan metodologi yang sama dengan penelitian ini, sebaiknya jumlah jurnalis yang di wawancara, pada stasiun televisi yang berbeda, menjadi lebih banyak lagi dari penelitian ini untuk memperkaya data yang ada.

\section{REFERENSI}

Fish, Adam Richard. (2012). Reforming the American Public Sphere: The Media Reform Models of progressive Television Journalist in the Era of Internet Convergence and Neoliberalism. University of California. Los Angeles. Diunduh dari search.proquest.com, pada tanggal 4 Februari 2016

Hill, Charles WL., Jones, Gareth R., Galvin, Peter. (2004). Strategic Management: An Integrated Approach. Jon Wiley \& Sons Australia Ltd. Singapore

Kotler, Philip., Keller, Kevin Lane. (2012). Marketing Management. Pearson. USA

Kovach, Bill., Rosentiel, Tim. (2006). Sembilan Element Jurnalisme. Pantau.

Kuswarno, Engkus. (2013). Metodologi Penelitian Komunikasi Fenomenologi: Konsepsi, Pedoman, dan Contoh Penelitiannya. Widya Padjadjaran.

Noor, Henry Faizal. (2010). Ekonomi Media. RAJAWALI PERS. Jakarta

Persatuan Perusahaan Periklanan Indonesia. (2015). Indonesia Media Guide 2015.

Percy, Larry., Rossiter, John R., Elliot, Richard. (2004). Strategic Advertising Management.Oxford University Press. USA

Percy, Larry., Elliot, Richard. (2012). Strategic Advertisng Management. Oxford University Press. USA

Porter, Michael E. (1994). Keunggulan Bersaing: Menciptakan dan Mempertahankan Kinerja yang Unggul. Bina Rupa Aksara. Jakarta Barat 
PT. FORTUNE INDONESIA TBK. (2014). Film Dokumenter HAJAR: Opportunity from Challenge. SEMBILAN MATAHARI DAN FORTUNE INDONESIA. Diunduh dari http://foru.co.id/2013/id/\#, pada tanggal 2 Januari 2016 